\title{
Effects of Thermal and Non-Thermal Pre-Processing Methods on Physical Parameters of Jack bean (Canavalia ensiformis) Seed
}

\author{
*1ODEDEJI, JO; ${ }^{2}$ AKANDE, EA; ${ }^{2}$ FAPOJUWO, OO; ${ }^{1}$ OJO, A \\ ${ }^{1}$ Osun State Polytechnic, Iree. Osun State, Nigeria. \\ ${ }^{2}$ Ladoke Akintola University of Technology, Ogbomosho. Oyo State, Nigeria. \\ *Corresponding Author Email address: odedeji2014@gmail.com
}

\begin{abstract}
Effects of thermal and non-thermal pre-processing methods on the physical parameters of jackbean seed were investigated. The bean was subjected to three pre-processing methods roasting and autoclaving which are thermal and sprouting a non-thermal pre-processing method. The physical parameters evaluated include length, width and thickness which were done by the use of digital venier caliper, sphericity index by the use of formula and aspect ratio which is the ratio between length and width. The results of physical characterization revealed that all the pre-processing methods used had effects on the seed. With roasting, there was decrease in all these parameters except sphericity index: length 19.00$15.00 \mathrm{~mm}$, width $13.00-11.00 \mathrm{~mm}$, thickness $10.75-10.55 \mathrm{~mm}$ and sphericity index $72.88-80.20 \%$. The aspect ratio decreased with pre-processing time for all the treatments used from 1.46-1.33. Kernel density $\left(\mathrm{g} / \mathrm{cm}^{3}\right)$, bulk density $\left(\mathrm{g} / \mathrm{cm}^{3}\right)$ and density ratio for the untreated seed were $1.24,0.73$ and 0.59 respectively. However, with autoclaving and sprouting, there was increase in length from 19.00-24.00 mm, width 13.00-18.00 mm, thickness $10.75-11.10 \mathrm{~mm}$ but a decrease in sphericity index (72.88- $67.46 \%)$ as the pre-processing time increased. These results are very useful in designing of processing equipment for the jackbean seeds thus, encouraging the industrial utilization of the seed.
\end{abstract}

\section{DOI: https://dx.doi.org/10.4314/jasem.v22i9.04}

Copyright: Copyright $@ 2018$ Odedeji et al. This is an open access article distributed under the Creative Commons Attribution License (CCL), which permits unrestricted use, distribution, and reproduction in any medium, provided the original work is properly cited.

Keywords: Jackbean, roasting, autoclaving, sprouting

Legumes are all plants of the pea and beans family (Leguminoceae) which comprises the Caesalpinacea (Senna family), Mimosaceae (Locust bean) and Pappilionaceae (Agbolade, 2012). They are of economic importance as cheap sources of protein, energy and other nutrients in the diets in most developing countries of the world. Legumes seeds contained as high as 20 to $50 \%$ protein, which in general runs above twice the level found in cereal grains and significantly more than the level in convectional root crops (Chel-Guerrero, et al., 2002). The protein is high in lysine content (Duranti and Gaius, 1997). Legumes protein contained most of the essential and non-essential amino acids in proportion very similar to those of animal protein. (NSRL, 2002). The two categories of legumes include major ones e.g. soybean, groundnut, cowpea, african locust bean and minor ones also known as neglected or underutilized include Bambara groundnut, lima beans, pigeon peas, Lablab, Jackbean etc (Aremu et al., 2006). Jackbean (Canavalia ensiformis) - 'Sese nla' (Yor), family of leguminoceae is a tropical plant of the pea family with purple clustering flowers, native to tropical America, Southern United State (Agbolade, 2012). It is one of the minor legumes in Nigeria and other West African countries. It is rich in most essential amino acids, including those deficient in wheat (Lawal and
Adebowale, 2005). It is usually planted in Nigeria as ornamental plant and in some places as "snake expellant". Industrially, the crop is yet to enjoy adequate processing. The handling is done by the farmer and local processors manually.

The physical properties of seeds and food generally go a long way in the design and fabrication of suitable machine and equipment for their handling and processing (Akande, 2008). There is paucity of information on the effect of pre-processing methods on the physical parameters of jackbean (Canavalia ensiformis). This work is designed to establish the effect of roasting and autoclaving (thermal) and sprouting (non-thermal) as pre-processing methods on the physical parameters of the seed.

\section{MATERIALS AND METHODS}

Materials: The seeds of Jackbean (Canavalia ensiformis) was procured from Germ-plasm unit of International Institute of Tropical Agriculture (IITA), Ibadan, Oyo State, Nigeria. Shelling: The fruits (pods) after maturity (four months) were harvested from the parent plants and sun dried to $15 \%$ moisture content. The beans were removed from the pod by shelling. The Jackbean were thereafter winnowed to remove chaff. 
Roasting: The method reported by Adebiyi et al. (2002) was adopted for roasting of the Jackbean seed. Two hundred grammes (200 g) of the beans were roasted inside universal hot air regulated oven at 160 ${ }^{\circ} \mathrm{C}$ for 10, 20, 30, 40 and 50 minutes after cleaning and sorting operation. The beans were allowed to cool before evaluation of their physical parameters.

Autoclaving: Two hundred grammes $(200 \mathrm{~g})$ of the seed samples were autoclaved at $151 \mathrm{~b}$ pressure (121 $\left.{ }^{\circ} \mathrm{C}\right)$ in distilled water (1:10) bean: water for $30,60,90$ and 120 minutes. The autoclaved seeds were dehulled and oven dried at $55{ }^{\circ} \mathrm{C}$ (MODEL: YX-280A, England) to a moisture content of $12 \%$. The physical parameters were thereafter determined (Adegunwa $e t$ al., 2012).

Sprouting: Modified method of Hassan et al. (2006) was used for sprouting of the seed. $200 \mathrm{~g}$ of beans were steeped in $1500 \mathrm{ml}$ of water for 24 hours at room temperature. The steeped beans were drained while allowing each portion to malt for 5, 6, 7, 8, and 9 days respectively. The malted beans were dried in a cabinet dryer at $45 \pm 2{ }^{\circ} \mathrm{C}$ for $6 \mathrm{hrs}$ to moisture content of $12 \%$. The plumules were removed before determining the physical parameters.

Measurement of Length and width: The length and width of 100 seeds randomly selected was measured with digital vernier caliper. This was repeated five times. The arithmetic mean was determined and this was used to compute the length and width and reported in millimeter (Ghaniyah and Abiodun, 2016).

Measurement of Thickness: The thickness of the randomly selected seed was measured using digital vernier calliper. Fifty (50) seeds from every 500 were randomly picked and measured. This was repeated five times and the average taken (Akande et al., 2014 and Ghaniyah and Abiodun, 2016.

The Sphericity Index (SI): The size of the seeds was measured by taken 100 each of randomly picked seeds. Their length (L), width (W) and thickness (T) were measured using venier caliper. The sphericity index was determined by using the formula of Dhineshkumar, Ramasamy and Ksudha (2015).

$\mathrm{SI}=\frac{(\mathrm{L} \times \mathrm{W} \times \mathrm{T})^{\frac{1}{3}}}{\mathrm{~L}} \times 100 \%$

The Aspect Ratio (AR): This is the ratio between the length and the width of the seed. The length and width of the sample were taken for each of the 100 randomly picked seeds, the ratio of these parameters were determined and the mean was calculated using the method described by Dhineshkumar, Ramasamy and Ksudha (2015).

Seed Density (SD): The seed density was determined for untreated Jackbean alone using the method of Dhineshkumar, Ramasamy and Ksudha, 2015.

Bulk Density (BD): The bulk density was done for untreated jackbean alone. The volume and weight of sample placed in $25 \mathrm{~cm}^{3}$ measuring cylinder under constant condition was measured and expressed in $\mathrm{g} / \mathrm{cm}^{3}$ (AOAC 1990).

Density Ratio: This was done only for raw jackbean. Raw jackbean was carefully selected and bulk and seed densities were determined. The density ratio was evaluated by finding the ratio of the bulk density to the seed density of the sample.

\section{RESULTS AND DISCUSSION}

Effect of Roasting on Physical Parameters of Jackbean Seed: The result of effect of roasting on physical parameters of jackbean is as presented in table 1. It was discovered that the length for untreated sample $\left(R_{0}\right)$ recorded $19.00 \mathrm{~mm}$, which gradually decreased as result of roasting. Roasting as a form of pretreatment incorporates high temperature to food products and may lead to alteration on the basic structure of the raw material. Roasting is a dry heat treatment leading to moisture removal and consequent shrinkage of the seed (Knoor, 1999; Fellow, 2000). The length was found to reduce steadily as roasting time was on the increase. It reduced from $19.00 \mathrm{~mm}$ in $R_{o}$ to $18.00 \mathrm{~mm}$ in $R_{1}$ and $R_{2}$ and $16.00 \mathrm{~mm}$ in $R_{3}$ and $R_{4}$ and finally to $15.00 \mathrm{~mm}$ in $R_{5}$. Samples $R_{3}$ and $R_{4}$ were not significantly different at $\mathrm{P} \leq 0.05$.

There was gradual dehydration of the seed because of increase in roasting time, which might be responsible for the reduction in length. The same trend was observed for width and thickness. This reduced from 13.00 in $R_{o}$ to 11.00 in $R_{5}$. Due to the dehydrating effect of roasting as a form of pretreatment, there was a steady decrease in the width of jackbean seed. The seed recorded similar value for $R_{0}$ and $R_{1}, R_{2}$ and $R_{3}$ and $R_{4}$ and $R_{5}$ respectively with steady reduction in that order. $R_{o}$ and $R_{1}$ recorded $13.00 \mathrm{~mm}, R_{2}$ and $R_{3}$ recorded $12.00 \mathrm{~mm}$ while $\mathrm{R}_{4}$ and $\mathrm{R}_{5}$ recorded 11.00 $\mathrm{mm}$. The thickness reduced from $10.75 \mathrm{~mm}$ in $R_{o}$ to $10.55 \mathrm{~mm}$ in both $\mathrm{R}_{4}$ and $\mathrm{R}_{5}$ respectively. $\mathrm{R}_{1}$ recorded $10.70 \mathrm{~mm}, \mathrm{R}_{2} 10.62 \mathrm{~mm}$ and $10.60 \mathrm{~mm}$ in $R_{3}$. Samples, $R_{4}$ and $R_{5}$ were not significantly different from one another at $\mathrm{P} \leq 0.05$. Sphericity index (\%) displayed increment in this parameter. There was increase from 72.88 in both $\mathrm{R}_{\mathrm{o}}$ to 75.44 in $\mathrm{R}_{2}$. Samples $R_{5}$ recorded the highest value of 80.20 while the least 
value of 73.27 was recorded by sample $R_{2}$. All the values recorded for sphericity index were greater than 0.83 that was reported for locust bean seed. This revealed that the seed would roll easily inside hopper of dehuller in the industrial processing of the seed. This is needed in designing of this processing equipment for the seed (Oyelade, et al., 2005; Olajide and Ade-Omowaye, 1991). There was serpentine order of presentation in the aspect ratio of the samples. There was slight decrease in value from 1.46 in $R_{o}$ to 1.39 in $\mathrm{R}_{1}$ and sudden increase to 1.50 in $\mathrm{R}_{2}$ which reduced to 1.33 in $R_{3}$. Sample $R_{4}$ recorded 1.46 and final reduction to 1.36 in $\mathrm{R}_{5}$.

Effect of Autoclaving on the Physical Parameters of Jackbean Seeds: The physical properties of kernels, grains and seeds are necessary for the design of equipment to handle, transport, process and store the crop (Adelakun, 2009). These properties are very important in design and operation of specific equipment or machines in food materials handling (Akande, 2008). The Physical characteristics measured include the length, breadth, width, sphericity index, aspect ratio and density characteristics. The values obtained for these parameters are as presented in Table 2. There was gradual increase in length of the seeds as the autoclaving time was on the increase. The untreated sample $\left(\mathrm{T}_{\mathrm{o}}\right)$ recorded $19.00 \mathrm{~mm}$, this increased to $21.00 \mathrm{~mm}$ when the autoclaving time was $30 \mathrm{~min}$ and to $22.00 \mathrm{~mm}$ at $60 \mathrm{~min}$ of autoclaving. There was no further increase in the length of the seed after this time. The increase might be due to the absorption of water (hydration) because of increase in temperature and time (Odedeji, 2010; Okpala, 2010) leading to swelling of the seed. Maximum increase in length was recorded at 60,90 and $120 \mathrm{~min}$ of autoclaving because of maximum absorption of water. The recorded values for autoclaving at these times were not significantly different from one another but were significantly different from untreated sample $\left(\mathrm{T}_{\mathrm{o}}\right)$ and sample autoclaved for $30 \mathrm{~min}$. The same trend was observed for width and thickness. It was observed that the width was on the increase as the autoclaving time was on the increase. The value recorded for untreated sample $\left(\mathrm{T}_{\mathrm{o}}\right)$ was $13.00 \mathrm{~mm}$. There was no increment when the sample was autoclaved for $30 \mathrm{~min}$ but the width increased to $14.00 \mathrm{~mm}$ at $60 \mathrm{~min}$ and $16.00 \mathrm{~mm}$ at $90 \mathrm{~min}$. There was no further increase in the width at $120 \mathrm{~min}$ of autoclaving. This might also be due to maximum absorption of water at this level. The untreated sample $\left(\mathrm{T}_{\mathrm{o}}\right), \mathrm{T}_{1}$ and $\mathrm{T}_{2}$ were not significantly different at $\mathrm{P} \leq 0.05$. $\mathrm{T}_{3}$ and $\mathrm{T}_{4}$ were not equally significantly the same but significantly different from $T_{0}, T_{1}$ and $T_{2}$ respectively. There was steady increase in the thickness of the seeds as the autoclaving time increased. The value recorded for $T_{o}$ was $10.75 \mathrm{~mm}$ which steadily increased to $10.79 \mathrm{~mm}$ at $30 \mathrm{~min}\left(\mathrm{~T}_{1}\right)$. Maximum thickness was recorded at $120 \mathrm{~min}(11.10 \mathrm{~mm})$ of autoclaving. This might be due to swelling of the seed. The values recorded were all significantly different from one another at $\mathrm{P} \leq 0.05$ except at $\mathrm{T}_{2}$ and $\mathrm{T}_{3}$. The sphericity index $(\%)$ for $\mathrm{T}_{\mathrm{o}}$ was found to be $72.88 \%$. There was steady decrease in this parameter as the autoclaving time increased. The recorded values ranged between 67.98 and 71.59 for treated samples. The highest value for treated sample was recorded at $120 \mathrm{~min}$ of autoclaving. All the values were significantly different from one another at $\mathrm{P} \leq 0.05$. The sphericity index was found to be higher than the value recorded for locust bean seed (0.83), which was interpreted as presenting difficulty in getting locust bean seed roll easily (Olajide and Ade-Omowaye, 1991). The higher values recorded for untreated and treated Jackbean seeds suggest that it will roll easily. This property is important in the design of hoppers and dehullers for the seed (Olajide and Ade-Omowaye, 1991; Oyelade et al., 2005). The aspect ratio, which is the ratio between the length and the width of the seed recorded 1.46 for sample $T_{0}$ which increased to 1.62 for sample $T_{1}$ and reduced back to 1.57 for sample $T_{2}$ and there was further reduction to 1.38 for $T_{3}$ and $T_{4}$. The density characteristics of Jackbean seed determined include; kernel density $\left(\mathrm{g} / \mathrm{cm}^{3}\right)$, bulk density $\left(\mathrm{g} / \mathrm{cm}^{3}\right)$ and density ratio. These parameters are used in predicting the grain machine operation. The density has also been established to be proportional to the material components in a grain food sample. It is good in calculating the throughput capacity of the machine and the materials samples in relation to the power of the machine (Romeo, 2000). The values obtained for kernel density, bulk density and density ratio were $1.24 \pm 0.02\left(\mathrm{~g} / \mathrm{cm}^{3}\right) ; 0.73 \pm 0.01\left(\mathrm{~g} / \mathrm{cm}^{3}\right)$ and $0.59 \pm$ $0.01 \%$ respectively. The kernel density was higher than $1.00 \mathrm{~g} / \mathrm{cm}^{3}$ which implies that the seeds are heavier than water and this characteristic can be used to design a separation or cleaning process for the seeds since their lighter fractions will float (Olajide and Ade-Omowaye, 1991; Oyelade et al., 2005). Bulk density determines the capacity of storage and transport systems. Density is useful for separation equipment; porosity of the mass of seeds determines the resistance to airflow during aeration and drying (Kachru et al., 1994). The bulk density recorded for Jackbean flour is higher than that recorded for untreated Jackfruit seeds $0.80 \mathrm{~g} / \mathrm{cm}^{3}$ (Odoemelan, 2005). This is expected because of the compactness of the seed. Bulk density is a measure of heaviness of a flour or food sample. It is important for determining packaging requirements, materials handling and application in wet processing in food industry (Ocloo et al., 2010). 
Table 1 Effect of Roasting on Physical Parameters of Jackbean Seeds

\begin{tabular}{lcccccc}
\hline \multicolumn{1}{c}{ Parameters } & $\mathbf{R}_{\mathbf{o}}$ & $\mathbf{R}_{\mathbf{1}}$ & $\mathbf{R}_{\mathbf{2}}$ & $\mathbf{R}_{3}$ & $\mathbf{R}_{4}$ & $\mathbf{R}_{5}$ \\
\hline Length $(\mathrm{mm})$ & $19.00 \pm 0.01_{\mathrm{a}}$ & $18.00 \pm 0.01_{\mathrm{ab}}$ & $18.00 \pm 0.01_{\mathrm{ab}}$ & $16.00 \pm 0.01_{\mathrm{bc}}$ & $16.00 \pm 0.01_{\mathrm{bc}}$ & $15.00 \pm 0.01_{\mathrm{c}}$ \\
Width $(\mathrm{mm})$ & $13.00 \pm 0.01_{\mathrm{a}}$ & $13.00 \pm 0.01_{\mathrm{a}}$ & $12.00 \pm 0.01_{\mathrm{b}}$ & $12.00 \pm 0.01_{\mathrm{b}}$ & $11.00 \pm 0.01_{\mathrm{c}}$ & $11.00 \pm 0.01_{\mathrm{c}}$ \\
Thickness (mm) & $10.75 \pm 0.01_{\mathrm{a}}$ & $10.70 \pm 0.01_{\mathrm{b}}$ & $10.62 \pm 0.01_{\mathrm{c}}$ & $10.60 \pm 0.01_{\mathrm{bc}}$ & $10.55 \pm 0.01_{\mathrm{c}}$ & $10.55 \pm 0.01_{\mathrm{c}}$ \\
Sphericity Index $(\%)$ & $72.88 \pm 0.01 \mathrm{f}$ & $75.44 \pm 0.01_{\mathrm{d}}$ & $73.27 \pm 0.01_{\mathrm{e}}$ & $79.20 \pm 0.01_{\mathrm{b}}$ & $76.82 \pm 0.01_{\mathrm{c}}$ & $80.20 \pm 0.01_{\mathrm{a}}$ \\
Aspect Ratio & $1.46 \pm 0.01_{\mathrm{b}}$ & $1.39 \pm 0.01_{\mathrm{c}}$ & $1.50 \pm 0.01_{\mathrm{a}}$ & $1.33 \pm 0.01_{\mathrm{e}}$ & $1.46 \pm 0.01_{\mathrm{b}}$ & $1.36 \pm 0.01_{\mathrm{d}}$ \\
\hline
\end{tabular}

Values are means and standard deviation of triplicate determinations; Means followed by the same alphabet in a row are not significantly different $(\mathrm{P} \leq 0.05)$ according LSD test $\mathrm{Ro}=$ Raw (Untreated Jackbean Flour); $R_{I}=$ Roasted Jackbean Flour at $160^{\circ} \mathrm{C}$ for 10 min $; R_{2}=$ Roasted Jackbean Flour at $160^{\circ} \mathrm{C}$ for $20 \mathrm{~min} ; R_{3}=$ Roasted Jackbean Flour at $160^{\circ} \mathrm{C}$ for $30 \mathrm{~min} ; R_{4}=$ Roasted Jackbean Flour at $160^{\circ} \mathrm{C}$ for $40 \mathrm{~min}$; $R_{5}=$ Roasted Jackbean Flour at $160^{\circ} \mathrm{C}$ for $50 \mathrm{~min}$

Table 2. Effect of Autoclaving on Physical Parameters of Jackbean Seeds

\begin{tabular}{llllll}
\hline Parameters & $\mathbf{T}_{\mathbf{0}}$ & $\mathbf{T}_{\mathbf{1}}$ & $\mathbf{T}_{\mathbf{2}}$ & $\mathbf{T}_{\mathbf{3}}$ & $\mathbf{T}_{\mathbf{4}}$ \\
\hline Length $(\mathrm{mm})$ & $19.00 \pm 0.01_{\mathrm{c}}$ & $21.00 \pm 0.01_{\mathrm{b}}$ & $22.00 \pm 0.01_{\mathrm{a}}$ & $22.00 \pm 0.01_{\mathrm{a}}$ & $22.00 \pm 0.01_{\mathrm{a}}$ \\
Width $(\mathrm{mm})$ & $13.00 \pm 0.01_{\mathrm{b}}$ & $13.00 \pm 0.01_{\mathrm{b}}$ & $14.00 \pm 0.01_{\mathrm{b}}$ & $16.00 \pm 0.01_{\mathrm{a}}$ & $16.00 \pm 0.01_{\mathrm{a}}$ \\
Thickness (mm) & $10.75 \pm 0.01_{\mathrm{d}}$ & $10.79 \pm 0.01_{\mathrm{c}}$ & $10.86 \pm 0.01_{\mathrm{b}}$ & $10.88 \pm 0.01_{\mathrm{b}}$ & $11.10 \pm 0.01_{\mathrm{a}}$ \\
Sphericity Index $(\%)$ & $72.88 \pm 0.01_{\mathrm{a}}$ & $68.49 \pm 0.01_{\mathrm{d}}$ & $67.98 \pm 0.01_{\mathrm{e}}$ & $71.12 \pm 0.01_{\mathrm{c}}$ & $71.59 \pm 0.01_{\mathrm{b}}$ \\
Aspect Ratio & & & & & \\
Kernel Density $\left(\mathrm{g} / \mathrm{cm}^{3}\right)$ & $1.24 \pm 0.02$ & ND & ND & ND & ND \\
Bulk Density $\left(\mathrm{g} / \mathrm{cm}^{3}\right)$ & $0.73 \pm 0.01$ & ND & ND & ND & ND \\
Density Ratio & $0.59 \pm 0.01$ & ND & ND & ND & ND \\
\hline
\end{tabular}

Values are means and standard deviation of triplicate determinations $(n=3) ;$ Means followed by the same alphabet within the same row are not significantly different $(P \leq 0.05)$ according to $L S D$ test; $N D=$ Not determined; $T_{o}=$ Raw (untreated) Jackbean flour; $T_{1}=$ Autoclaved Jackbean flour at $121{ }^{\circ} \mathrm{C}$ for $30 \mathrm{~min} ; \mathrm{T}_{2}=$ Autoclaved Jackbean flour at $121{ }^{\circ} \mathrm{C}$ for $60 \mathrm{~min} ; \mathrm{T}_{3}=$ Autoclaved Jackbean flour at $121{ }^{\circ} \mathrm{C}$ for 90 min; $T_{4}=$ Autoclaved Jackbean flour at $121{ }^{\circ} \mathrm{C}$ for $120 \mathrm{~min}$

Table 3 Effect of Sprouting on Physical Parameters of Jackbean Seeds

\begin{tabular}{lllllll}
\multicolumn{1}{c}{ Parameters } & $\mathbf{D}_{\mathbf{0}}$ & $\mathbf{D}_{\mathbf{1}}$ & $\mathbf{D}_{\mathbf{2}}$ & $\mathbf{D}_{\mathbf{3}}$ & $\mathbf{D}_{\mathbf{4}}$ & $\mathbf{D}_{\mathbf{5}}$ \\
\hline Length $(\mathrm{mm})$ & $19.00 \pm 0.01_{\mathrm{c}}$ & $19.00 \pm 0.01_{\mathrm{c}}$ & $21.00 \pm 0.01_{\mathrm{b}}$ & $22.00 \pm 0.01_{\mathrm{b}}$ & $24.00 \pm 0.01_{\mathrm{a}}$ & $24.00 \pm 0.01_{\mathrm{a}}$ \\
Width $(\mathrm{mm})$ & $13.00 \pm 0.01_{\mathrm{e}}$ & $14.00 \pm 0.01_{\mathrm{d}}$ & $15.00 \pm 0.01_{\mathrm{c}}$ & $15.00 \pm 0.01_{\mathrm{c}}$ & $16.00 \pm 0.01_{\mathrm{b}}$ & $18.00 \pm 0.01_{\mathrm{a}}$ \\
Thickness $(\mathrm{mm})$ & $10.75 \pm 0.01_{\mathrm{d}}$ & $10.80 \pm 0.01$ & $11.10 \pm 0.01_{\mathrm{a}}$ & $11.10 \pm 0.01$ & $11.05 \pm 0.01_{\mathrm{b}}$ & $11.05 \pm 0.01_{\mathrm{b}}$ \\
Sphericity Index $(\%)$ & $72.88 \pm 0.01_{\mathrm{b}}$ & $74.82 \pm 0.01_{\mathrm{a}}$ & $72.28 \pm 0.01_{\mathrm{c}}$ & $70.07 \pm 0.01_{\mathrm{d}}$ & $67.46 \pm 0.01_{\mathrm{f}}$ & $70.16 \pm 0.01_{\mathrm{e}}$ \\
Aspect Ratio & $1.46 \pm 0.01_{\mathrm{c}}$ & $1.36 \pm 0.01_{\mathrm{e}}$ & $1.40 \pm 0.01_{\mathrm{d}}$ & $1.47 \pm 0.01_{\mathrm{b}}$ & $1.50 \pm 0.01_{\mathrm{a}}$ & $1.33 \pm 0.01_{\mathrm{f}}$ \\
\hline
\end{tabular}

Values are means and standard deviation of triplicate determinations; Values with similar alphabet are not significantly different $(P \leq 0.05)$ according to LSD test $; D_{o}=$ Raw Jackbean Flour; $D_{1}=$ Sprouted Jackbean Flour day 5; $D_{2}=$ Sprouted Jackbean Flour day 6; $D_{3}=$ Sprouted Jackbean Flour day 7; $D_{4}=$ Sprouted Jackbean Flour day 8, $D_{5}=$ Sprouted Jackbean Flour day 9

Effect of Sprouting on Physical Parameters of Jackbean Seeds: The result of the effect of malting on the physical parameters of jackbean is as presented in table 3. Sprouting is a natural biological process of all superior plant by which seed comes out of its latency stage once the minimal environmental conditions needed for its growth and development, such as humidity, temperature, nutrients etc are provided. (Sangronis and Machado, 2005). There was gradual increase in the length of the seed as sprouting period increased. There was no noticeable change in length of the seed on the first appearance of sprout but there was gradual increase in the length of the seed from 19.00 $\mathrm{mm}$ in $\mathrm{D}_{\mathrm{o}}$ to $21.00 \mathrm{~mm}$ in $\mathrm{D}_{2}$. The gradual increment continued to day 9 of sprouting $\left(D_{5}\right)$ which represented the highest value $(24.00 \mathrm{~mm})$. The increase in length might be due to hydration of the seed during sprouting of the seed leading to temporary swelling and bulging of the seed. Samples $\mathrm{D}_{\mathrm{o}}$ and $\mathrm{D}_{1}, \mathrm{D}_{2}$ and $\mathrm{D}_{3}$ and $\mathrm{D}_{4}$ and $\mathrm{D}_{5}$ were not significantly different from one another but each pair is significantly different at $P \leq 0.05$. There was gradual increase in the width of the seeds as the sprouting day progressed. Maximum increase (18.00 $\mathrm{mm}$ ) was recorded at the maximum period of sprouting $\left(\mathrm{D}_{5}\right)$ while the least $(14.00 \mathrm{~mm})$ was recorded at the first day of sign of sprout $\mathrm{D}_{1}$. Samples $\mathrm{D}_{2}$ and $\mathrm{D}_{3}$ were not significantly different from one another but significantly different from samples $D_{0}$ and $\mathrm{D}_{5}$. Moisture uptake (hydration) might equally be responsible for the increase in width. The thickness was equally increasing steadily as the sprouting day progressed. Maximum increase in thickness was recorded at $\mathrm{D}_{2}$ and $\mathrm{D}_{3}(11.10 \mathrm{~mm})$. It was observed that there was slight decrease in the thickness in $\mathrm{D}_{4}$ and $\mathrm{D}_{5}$ respectively $(11.05 \mathrm{~mm})$. This might be due to uptake of nourishment from the parent seed and photosynthetic process of the sprout for survival. It was observed that the colour of the sprout at this period was becoming more green making it suitable for photosynthesis.

The values for sphericity index for untreated $\left(D_{0}\right)$ and treated samples ranged from $67.46-72.88$. The least value (67.46) was recorded by sample $\mathrm{D}_{4}$. All the treated samples recorded lower values compared to the untreated sample $\left(D_{0}\right)$. The values recorded for sphericity index were greater than 0.83 reported for locust bean seed (Olajide and Ade- Omowaye, 1991). 
The serpentine order as were observed in the other two pretreatments (autoclaving and roasting) for aspect ratio was equally observed for sprouting. All the samples were significantly different from one another. Maximum value (1.50) for this parameter was recorded at $\mathrm{D}_{4}$ while the least value (1.33) was recorded at the last day of sign of sprout $\left(\mathrm{D}_{5}\right)$.

Conclusion: The study revealed that the preprocessing methods recorded higher values for sphericity index of the samples. This property is important in the design of hoppers and dehullers. The density characteristics of the seed is very useful in calculating the through-put capacity of processing machine, parameter like bulk density is useful for separation equipment, determination of packaging requirements, materials handling and application in wet processing in food industry. Jackbean is therefore a seed with industrial potential.

\section{REFERENCES}

Adebiyi, AP; Adeyemi, IA; Olorunda, OA (2002). Effects of Processing Conditions and Packaging Materials on the Quality Attributes of DryRoasted Peanuts. J. Sci. Fd. Agricul. 82: 1465 1471.

AOAC (1990). Official Methods of Analysis. 15 Edition, Association of Official Analytical Chemist Washington D.C.

Adegunwa, MO; Adebowale, AA; Solano, EO (2012). Effect of Thermal Processing on the Biochemical Composition, Anti-nutritional Factors and Functional Properties of Beniseed (Sesamum Indicum) Flour. Amer. J. of Biochem. and Mol. Biol. 2(3): 175 - 182.

Adelakun, OE (2009). Effect of Pre-treatment on some Quality Attributes of Okra (Abelmoschus esculentus) Seeds and its Flour. A Ph.D Thesis Submitted to the Department of Food Science and Engineering, Ladoke Akintola University of Technology, Ogbomoso, Oyo State Nigeria. p. $41-43$.

Agbolade, JO (2012). Biosystematics Studies on Miscellaneous Legume. A Ph.D Thesis Submitted to the Department of Botany, College of Natural and Applied Sciences. Federal University of Agriculture, Abeokuta.

Akande, EA (2008). Physical Characteristics, Nutritive and Preservative Potentils of Wild Pepper (Erythrococca anomala, Benth) Seeds. A Ph.D Thesis Submitted to the Department of
Food Technology, University of Ibadan, Ibadan, Oyo State, Nigeria. p. $45-47$.

Akande, EA; Odedeji, JO; Agbolade, JO (2014). Physical Characterization and Physicochemical Properties of Jackbean (Canavalia ensiformis). Interl. J. of Engr. and Tech. Res. 2 (8): 230 - 232

Aremu, MO; Olaofe, O; Akintayo, TE (2006). A Comparative Study on the Chemical and Amino Acid Composition of some Nigeria Underutilized Legume Flours: Pak. J. of Nutr. 5(1): $34-38$

Chel-Guerrero, L; Perez-Flores, V; Bentacur-Ancona, D; Davila-Ortiz, G (2002). Functional properties of flours and protain isolate from Phaseolus lunatus and Canavalia ensiformis seeds. J. of Agricul. Fd. Chem. 50: 584- 591

Dhineshkumar, V; Ramasamy, D; Sudha, K (2015). Physical and Engineering Properties of Pomegranate Fruit and Arils. Interl. J. of Farm Sci. 5(3): 89 - 97.

Duranti, M; Gaius, C (1990). Legume seeds: Proteins Content and Nutritional Value. Field Crops Res. 53: $31-45$

Ghaniyah, OA; Abiodun, AO (2016). Physical, Proximate and Anti-nutritional Composition of African Yam Bean (Sphenostylis stenocarpa) Seeds Varieties. J. of Fd. Res. 5 (2) 67-69

Hassan, AB; Ahmed, IAM; Osman, M; Eltayeb, NM; Osman, GA; Babiker, EE (2006). Effect of processing treatments followed by fermentation on protein content and digestibility of Pear millet (Pennisetum typhoideum) cultivars. Pak. J. of Nutr. 5(1): 86-89.

Lawal, OS; Adebowale, KS (2005). The acetylated protein derivatives of Canavalia ensiformis ( Jackbean): A study of functional characteristics. LWT - Fd. Sci. and Technol. 39 (8): 918 - 929.

NSRL, (2002). National Soybean Research Laboratory. A Publication of National Soybean Research Laboratory on Soybean Processing from Field to Consumer (<www/NSRL).

Ocloo, FCK; Bansa, D; Boatin, R; Addam, T; Agbemavor, WS (2010). Physico-chemical, Functional and Pasting Characteristics of Flour Produced from Jackfruit (Artocarpus heterophyllus) Seeds. Agric. Biol. J. North Amer. 1(5). $903-908$. 
Odoemelan, SA (2005). Functional Properties of Raw and Heat Processed Jackfruit (Artocarpus heterophyllus) Flour. Pak. J. of Nutr. 4(6): $366-$ 370.

Olajide, JO; Ade-Omowaye, BIO (1999). Some Physical Properties of Locust Bean Seed. J. of Agricul. Engr. Res. 74, 213 - 215. .
Publications Ltd. Top Flour, New 17, Olorunsogo Street, Palmgrove-Shomolu, Lagos.

Oyelade, OJ; Odugbenro, PO; Abioye, AO; Raji, NC (2005). Some Physical Properties of African star apple (Chrysophyllum albidum) Seeds. J. of Fd. Engr. 67, $435-440$.

Wakil, SM; Kazeem, MO (2012). Quality Assessment of Weaning Food Produced from Fermented Cereal-Legume Blends using Starters. Interl. Fd. Res. J. 19(4): 1679 - 1685.

Owoso, OF; Aluko, O; Banjoko, OI (2000). Manual of Food Analysis and Quality Control. Concept 